\title{
Studi Pertumbuhan Awal Kuya Batok (Cuoro Ambonensis) di Kolam Kehutanan UNIB serta Implementasinya sebagai Bahan Ajar Zoologi Vertebrata
}

\author{
Indah Maryani $^{{ }^{*}}$, Aceng Ruyani ${ }^{1}$, Bhakti Karyadi ${ }^{1}$, Hery Suhartoyo ${ }^{2}$ \\ ${ }^{1}$ Program Studi Pascasarjana Pendidikan IPA, Universitas Bengkulu \\ ${ }^{2}$ Jurusan Kehutanan, Fakultas Pertanian, Universitas Bengkulu \\ *Email: indahmaryani64@gmail.com
}

\begin{abstract}
[Study of Kuya Batok (Cuoro Ambonensis) Early Growth's in UNIB Forestry Pond and its Implementation as Teaching Materials on Vertebrate Zoology]. The goal of this study was to know the growth of $C$. amboinensis in the ex-situ conservation area of the University of Bengkulu Forestry Pond during the 10 weeks study and 3 weeks continuous research, to know the condition of abiotic factor C. amboinensis in ex-situ conservation area of Forest Ponds of Bengkulu University, and to know the knowledge and understanding of the students about the early growth of $C$. amboinensis, the conservation concept at the University of Bengkulu Forestry Pond and the change of students conservation attitude by using teaching materials. Implementation of learning adoption of existing teaching material products "Technique Monitoring of Black-turtle Lineage of Coldhamii" (Astuti, 2016). The teaching material is in the form of a book entitled "Monitoring Technique of Turtle Shell (Cauro amboinensis)". The results of this study show that: a) The first study only received $1 C$. amboinensis for 10 weeks of observation and growth (weight, length, width, thickness, anteriorposterior arch, b) Abiotic factors in the conservation area supported growth of $C$. amboinensis and suitable for in situ conservation pond ex situ in UNIB, c) On the second observation release $15 C$. amboinensis by using 3 large trapp to conservation pond for 3 weeks and experiencing growth, $d$ ) condition of abioic factor become habitat C. amboinensis include: ground temperature 280C, water temperature 300C, relative humidity 80\%, soil pH 6, pH 7 water, turbidity 80, e) high knowledge of students about the existence of turtles $22.8 \%$ - to $77.2 \%$ on conservation $13 \%$ to $87 \%$, not in line with the conservation attitude of $34 \%$ to $66 \%$.
\end{abstract}

Keywords: Growth; C. amboinensis; abiotic factor; teaching material.

\begin{abstract}
ABSTRAK
Penelitian ini bertujuan untuk mengetahui pertumbuhan C. amboinensis di kawasan konservasi ex-situ Kolam Hutan Universitas Bengkulu selama 10 minggu penelitian dan 3 minggu penelitian berkelanjutan, untuk mengetahui kondisi faktor abiotik C. amboinensis di ex-situ kawasan konservasi Kolam Hutan Universitas Bengkulu, dan untuk mengetahui pengetahuan dan pemahaman siswa tentang pertumbuhan awal C. amboinensis, konsep konservasi di Kolam Hutan Universitas Bengkulu dan perubahan sikap konservasi siswa dengan menggunakan bahan ajar. Pelaksanaan pembelajaran adopsi produk bahan ajar yang ada "Teknik Pemantauan Silsilah Hitam-Penyu Coldhamii" (Astuti, 2016). Bahan ajar tersebut berupa buku berjudul "Teknik Pemantauan Penyu Shell (Cauro amboinensis)". Hasil penelitian ini menunjukkan bahwa: a) Penelitian pertama hanya menerima $1 \mathrm{C}$. amboinensis selama 10 minggu pengamatan dan pertumbuhan (berat, panjang, lebar, ketebalan, lengkung anterior-posterior, b) Faktor abiotik di kawasan konservasi mendukung pertumbuhan C. amboinensis dan cocok untuk kolam konservasi in situ ex situ di UNIB, c) Pada pengamatan kedua pelepasan $15 \mathrm{C}$. amboinensis dengan menggunakan 3 trapp besar ke kolam konservasi selama 3 minggu dan mengalami pertumbuhan, d) kondisi faktor abioat menjadi habitat $\mathrm{C}$. amboinensis meliputi: suhu tanah 280C, suhu air 300C, kelembaban relatif 80\%, pH tanah 6, pH 7 air, kekeruhan 80 , e) pengetahuan yang tinggi dari siswa tentang keberadaan kura-kura $22,8 \%$ - hingga $77,2 \%$ pada konservasi $13 \%$ hingga $87 \%$, tidak sejalan dengan sikap konservasi $34 \%$ hingga $66 \%$.
\end{abstract}

Kata kunci: Pertumbuhan; C. amboinensis; faktor abiotik; bahan ajar. 


\section{PENDAHULUAN}

Kura- kura secara umum dapat dibagi atas dua kelompok besar, yaitu kelompok Cryptodira yang umumnya dapat memasukan kepala kedalam perisai dan kelompok Pleurodira yang kepala dan lehernya hanya dibelokkan kesamping apabila bersembunyi (Iskandar, 2000). Hewan vertebrata ini menempati daerah yang cukup beraneka ragam dari yang hidup di air laut, air payau, air tawar hingga daratan, dataran rendah hingga perbukitan, hutan ataupun daerah terbuka. Kura- kura merupakan hewan bersisik, berkaki empat dan termasuk kedalam golongan reptil. Ciri khas yang mereka miliki adalah adanya batok yang keras dan kaku. Batok kura - kura terdiri atas dua bagian yaitu bagian dorsal yang disebut karapaks dan bagian ventral disebut plastron.

Provinsi Bengkulu memiliki sebaran kura- kura air tawar dan kura- kura terestrial di setiap kabupaten (Putri et al. 2011). Salah satunya adalah kura-kura Cuora amboinensis atau kura-kura batok. Kura- kura ini menkonsumsi makana seperti tumbuhtumbuhan tapi juga ikan dan udang (Iskandar, 2000).

\section{Menurut International Union for} Conservation of Nature (IUCN) memasukan jenis $C$. amboinensis kedalam kategori VU/Vulnerable (Rentan/mudah terancan punah) (IUCN, 2013). Salah satu penyebabnya yaitu adanya perilaku masyarakat yang memburu kura- kura, aktivitas perambahan hutan untuk kayu dan perkebunan, serta lemahnya pengaturan perdagangan kura- kura sebagai binatang peliharaan, sehingga dapat menekan keseimbangan populasi dan keanekaragaman jenis kura- kura serta dapat menghilangkan habitat dari kura- kura (Putri et al, 2011). Kura - kura adalah jenis hewan yang memiliki tabiat pemalu, lamban, dan menarik sehingga menarik perhatian anakanak atau orang dewasa untuk memeliharanya. Alasan lain hewan vertebrata ini dipelihara adalah benyak nya ragam dan corak warna dan bentuk karapaks pada kura- kura termasuk pada C. amboinensis.

Di provinsi Bengkulu khususnya di Universitas Bengkulu telah dilakukan kegiatan konservasi kura- kura. Melalui Program Pasca Sarjana S2 pendidikan IPA kegiatan konservasi ini dilakukan di kolam Kehutanan Universitas Bengkulu pada jenis Cuora amboinensis. Kegiatan ini dilaksanakan pada tanggal 7 November 2014 dengan tema "Unib Campus, A Safe Home For Turtles" dan jumlah kura- kura yang dilepas 45 ekor. Pasca Sarjana S2 pendidikan IPA juga berupaya menyelenggarakan pendidikan dan pengajaran secara berkualitas menyelenggarakan penelitian dan pengembangan IPA yang unggul dalam payung "Natural Conservation Eduucation for a Better Life", melaksanakan pengabdian pada masyarakat untuk memperkokoh wawasan "Natural Conservation Eduucation for a Better Life", menjalin kerja sama antar instansi lain agar menjadi pusat kajian IPA yang berwawasan dengan mengusung 3G (Green Teacher, Teaching Green, Green School).

Pendidikan Nasional memiliki fungsi untuk mengembangkan kemampuan dan membentuk watak serta peradapan bangsa yang bermartabat dalam rangka mencerdaskan kehidupan bangsa yang bertujuan untuk berkembangnya potensi peserta didik agar menjadi manusia yang beriman dan bertakwa kepada Tuhan Yang Maha Esa, berakhlak mulia, sehat, berilmu, cakap, kreatif, mandiri, dan menjadi warga bagian dari pendidikan sains dan sebagai salah satu mata pelajaran Negara yang demokratis serta bertanggung jawab (Depdiknas, 2008).

Dalam pencapaian tujuan dan mempermudah pemahaman dalam pembelajaran biologi dibutuhkan suatu metode yang selaras dengan kemajuan teknologi, yang erat kaitannya dalam rangka peningkatan kualitas pembelajaran. Salah satunya dengan penerapan pembelajaran individual, yang memberi kepercayaan pada kemampuan individu untuk mandiri dan cara yang efektif dalam penyampaian beberapa konsep yang akan di ajarkan dan dikemas dalam suatu media yang lebih menarik sehingga peserta didik dapat dengan mudah menyerap materi yang disampaikan. salah satunya dengn menggunakan bahan ajar.

Bahan ajar yang dikemas secara utuh dan sistematis, didalamnya memuat seperangkat pengalaman belajar yang terencana dan didesain untuk membantu peserta didik menguasai tujuan belajar yang spesifik. Dengan demikian di harapkan mahasiswa akan terlibat secara aktif sehingga akan tercipta suasana menyenangkan dan hasil belajar dapat dimaksimalkan. Berdasarkan hal tersebut pendidik diharapkan untuk 
mengembangkan bahan ajar sebagai salah satu sumber belajar. Kemampuan pendidik dalam merancang bahan ajar menjadi hal yang sangat berperan dalam menentukan keberhasilan proses belajar dan pembelajaran melalui pengembangan bahan ajar (Ramdani, 2012).

Berdasarkan informasi di atas, penulis ingin melakukan penelitian mengenai pertumbuhan awal populasi C. amboinensis di kolam kehutanan Universitas Bengkulu. Agar setiap langkah atau informasi yang dilakukan dan diperoleh dalam penelitian ini mudah dipahami oleh peserta didik, penulis menuangkan informasi dalam bentuk bahan ajar. Bahan ajar ini diharapkan dapat meningkatkan kemampuan pemahaman peserta didik dalam pembelajaran Biologi.

\section{METODE PENELITIAN}

Alat - alat untuk penelitian sains: Kamera, Kertas Ph, Jaring Kura-Kura, Timbangan Digital (CAMRY Electronic Kichen Scale), Meteran, Tali, Higrometer, Thermometer, Kepping Secchi, Soil Tester, Pengukur Ketinggian Air, Alat Tulis. Bahan :C.amboinensis. Alat untuk penelitian pembelajaran: bahan ajar dan angket. Subjek uji coba bahan ajar dalam penelitian ini ada 15 orang mahasiswa. Mahasiswa sasaran uji coba tersebut adalah mahasiswa semester 3 dan 5 yang berasal dari Program Studi Pendidikan Biologi, Fakultas Keguruan Dan Ilmu Pendidikan Universitas Bengkulu.

\section{Prosedur Penelitian Sains}

Prosedur penelitian sains yang dilakukan antara lain: 1) Penyiapan alat dan bahan, 2) Menentukan kode tagging, 3) Pengambilan data awal Cuora amboinensis, 4) Pengambilan data faktor Abiotik, 5) Merangkai traps, 6) Melepaskan kura- kura ke kolam konservasi.

\section{Prosedur Penelitian pembelajaran}

Jenis penelitian ini adalah penelitian pengembangan (Reserarch and Development) yaitu jenis penelitian yang mengembangakan suatu produk baru atau menyempurnakan produk yang telah ada sebelumnya dan dapat dipertanggung jawabkan dalam Ismi (2016). Peneliti mengadobsi bahan ajar yang sudah ada (Astuti et al. 2017) dengan judul "Pedoman dan Teknik Monitoring Kura- kura
Semi akuatik Studi pada Kura- kura Garis Hitam (C oldhamii).

\section{Analisis data penelitian sains}

Data yang diperoleh dari hasil penelitian ini disusun dalam bentuk tabel dan grafik, kemudian dianalisis secara deskriptif.

\section{Analisis data penelitian pembelajaran}

Persentase respon mahasiswa dihitung dengan menggunakan rumus berikut.

Persentase nilai $=\frac{\text { skor perolehan }}{\text { skor maksimum }} \times 100 \%$

Dengan kriteria :

$80 \%<\mathrm{x} \leq 100 \%$ : sangat tahu,

$60 \%<\mathrm{x} \leq 80 \%$ : tahu,

$40 \%<\mathrm{x} \leq 60 \%$ : cukup tahu

$20 \%<\mathrm{x} \leq 40 \%$ : kurang tahu

$\mathrm{X} \leq 20 \%$ : tidak tahu

\section{HASIL DAN PEMBAHASAN}

Penelitian ini bertujuan untuk mengamati pertumbuhan Cuora amboinensis di kolam konservasi, kolam kehutanan Universitas Bengkulu. Dengan melakukan pengukuran data morfologi $C$. amboinensis dan pengukuran terhadap faktor abiotik yang mendukung pertumbuhan kura- kura tersebut selama kura- kura tersebut dirilis dikolam konservasi. Kolam konservasi kehutanan UNIB ini berada di tengah- tengah lingkungan kampus yang mana sangat berdekatan dengan manusia. Kolam kehutanan ini dikelilingi oleh pepohonan besar dan gedung- gedung perkuliahan. Sekeliling kolam terdapat pondasi beton yang cukup tinggi. kolam ini memilik kedalaman 2- 3 meter didalamanya terdapat banyak ikan air tawar seperti Ikan Nila, Ikan Gabus, Ikan Mas. Dipinggirpinggir kolam ditanamai tanaman talas sebagai sumber makanan cauro. Saat musim hujan air kolam berubah menjadi coklat kotor sedangkan saat musim panas air kolam menjadi jernih bening. penelitian dilakukan selama 3 minggu dengan melepas 15 ekor C.amboinensis menggunakan 3 trap besar yang masing- masing trap diisi 5 ekor kurakura. Selama 3 minggu di dapat laju pertumbuhan morfologi data sebagai berikut: 
Tabel 1. Data laju pertumbuhanC.amboinensis di kolam konservasi pada trap 1

\begin{tabular}{|c|c|c|c|c|c|c|c|}
\hline $\begin{array}{l}\text { Kod } \\
\text { e } \\
\text { taggi } \\
\text { ng }\end{array}$ & $\begin{array}{l}\mathbf{S} \\
\mathbf{e} \\
\mathbf{x}\end{array}$ & $\begin{array}{l}\text { LP } \\
\text { bob } \\
\text { ot } \\
\text { tub } \\
\text { uh } \\
(\%)\end{array}$ & $\begin{array}{l}\text { LP } \\
\text { pan } \\
\text { jan } \\
\text { g } \\
\text { kar } \\
\text { apa } \\
\text { ks } \\
(\%)\end{array}$ & $\begin{array}{l}\text { LP } \\
\text { leba } \\
\text { r } \\
\text { kar } \\
\text { apa } \\
\text { ks } \\
(\%)\end{array}$ & $\begin{array}{l}\text { LP } \\
\text { teba } \\
\text { l } \\
\text { bad } \\
\text { an } \\
(\%)\end{array}$ & $\begin{array}{l}\mathbf{L} \\
\mathbf{P} \\
\text { le } \\
\text { ng } \\
\text { ku } \\
\text { ng } \\
\text { A } \\
\text { P } \\
( \\
\% \\
)\end{array}$ & $\begin{array}{l}\text { LP } \\
\text { leng } \\
\text { kun } \\
\text { g } \\
\text { mar } \\
\text { gina } \\
\text { l } \\
(\%)\end{array}$ \\
\hline $\mathrm{ABP}$ & $q$ & 9,88 & 1 & 1,27 & 25 & $\begin{array}{l}1, \\
70\end{array}$ & 2,01 \\
\hline $\mathrm{ACN}$ & $\hat{0}$ & 0,20 & 1,63 & 2,32 & 3,84 & $\begin{array}{l}1, \\
32\end{array}$ & 0,46 \\
\hline ACK & $q$ & $\begin{array}{l}39,8 \\
2\end{array}$ & 1,42 & 4,54 & 5,88 & $\begin{array}{l}0, \\
58\end{array}$ & 0 \\
\hline $\mathrm{ABN}$ & q & $\begin{array}{l}13,1 \\
8 \\
\end{array}$ & 1,53 & 1,85 & $\begin{array}{l}14,2 \\
8\end{array}$ & 0 & 0 \\
\hline $\mathrm{ACH}$ & $q$ & 8,89 & 0,76 & 0,92 & 3,44 & $\begin{array}{l}5, \\
36 \\
\end{array}$ & 0 \\
\hline
\end{tabular}

Tabel 2. Data laju pertumbuhanC.amboinensis di kolam konservasi pada Trap 2

\begin{tabular}{|c|c|c|c|c|c|c|c|}
\hline $\begin{array}{l}\text { Ko } \\
\text { de } \\
\text { tag } \\
\text { gin } \\
\text { g }\end{array}$ & $\begin{array}{l}\mathbf{S} \\
\mathbf{e} \\
\mathbf{x}\end{array}$ & $\begin{array}{l}\text { LP } \\
\text { bob } \\
\text { ot } \\
\text { tubu } \\
\text { h } \\
(\%)\end{array}$ & $\begin{array}{l}\text { LP } \\
\text { panj } \\
\text { ang } \\
\text { kara } \\
\text { paks } \\
(\%)\end{array}$ & $\begin{array}{l}\text { LP } \\
\text { leb } \\
\text { ar } \\
\text { ka } \\
\text { ra } \\
\text { pa } \\
\text { ks } \\
(\%) \\
)\end{array}$ & $\begin{array}{l}\text { LP } \\
\text { teba } \\
\text { l } \\
\text { bad } \\
\text { an } \\
(\%)\end{array}$ & $\begin{array}{l}\text { LP } \\
\text { len } \\
\text { gk } \\
\text { un } \\
\text { g } \\
\text { AP } \\
(\% \\
)\end{array}$ & $\begin{array}{l}\text { LP } \\
\text { leng } \\
\text { kun } \\
\text { g } \\
\text { mar } \\
\text { gina } \\
\text { l } \\
(\%)\end{array}$ \\
\hline $\begin{array}{c}\mathrm{AB} \\
\mathrm{X} \\
\end{array}$ & ㅇ & 4,63 & 0,53 & $\begin{array}{l}3,7 \\
0\end{array}$ & 1,11 & 0 & 0,43 \\
\hline $\begin{array}{c}\mathrm{AC} \\
\mathrm{L}\end{array}$ & 우 & 2,53 & 0,52 & $\begin{array}{l}1,3 \\
5\end{array}$ & 0 & 0 & 1,67 \\
\hline $\begin{array}{c}\mathrm{AC} \\
\mathrm{V}\end{array}$ & 우 & 9,32 & 0 & 0 & 3,70 & 0 & 3,44 \\
\hline $\begin{array}{c}\mathrm{AB} \\
\mathrm{W}\end{array}$ & 우 & $\begin{array}{l}19,3 \\
4\end{array}$ & 1,96 & $\begin{array}{l}3,4 \\
4\end{array}$ & 5,88 & $\begin{array}{l}0,5 \\
5\end{array}$ & 0 \\
\hline $\begin{array}{c}\mathrm{AB} \\
\mathrm{M}\end{array}$ & 우 & 6,75 & 1,66 & $\begin{array}{l}0,9 \\
5 \\
\end{array}$ & 5,35 & 0 & 0,65 \\
\hline
\end{tabular}

Laju pertumbuhan kura- kura di area konservasi mengalami fluktuasi yaitu kenaikan dan penurunan. Hal ini disebabkan pertumbuhan bersifat reversible atau naik turun dipengaruhioleh berbagai faktor interna maupun eksternal. Faktor yang mempengaruhi pertumbuhan antara lain berupa makan yang dikonsumsi dan kondisi lingkungan tempat tinggalnya. Sedangkan faktor yang menyebabkan menurunnya pertumbuhan disebabkan oleh penggunaan energi yang cukup besar sebagi akibat dari proses adaptasi pada lingkungan yang baru.

Faktor makan dapat dipengaruhi oleh kandungan protein hewani pada pakan.
Menurut Melinda (2007) Ikan nila merupakan salah satu jenis ikan air tawar yang banyak mengandung protein hewani yang sangat berguna untuk pertumbuhan . Protein yang terkandung didalam ikan nila sebesar 16- 24\% yang sangat baik untuk pertumbuhan (Rukmana, 2009).

Tabel 3. Hasil pengukuran faktor abiotik lingkungan area konservasi $C$. amboinensis Universitas Bengkulu.

\begin{tabular}{cc}
\hline Faktor Abiotik yang diukur & Hasil pengukuran \\
\hline Suhu air & $30^{\circ} \mathrm{C}$ \\
\hline Suhu tanah & $28^{\circ} \mathrm{C}$ \\
\hline Kelembapan udara & $80 \%$ \\
\hline $\mathrm{pH}$ air & 7 \\
\hline $\mathrm{pH}$ tanah & 6 \\
\hline Kekeruhan & 80
\end{tabular}

Berdasarkan Tabel 3 tersebut didapatkan hasil bahwa keadaan kolam kehutanan cukup baik untuk pertumbuhan kura- kura air tawar. Hasil pengukuran ini tidak jauh berbeda dengan penelitian Cempaka (2015) yang mengatakan bahwa C.amboinensis dapat hidup di daerah yang memiliki suhu air 250- 290 $\mathrm{C}, \mathrm{Ph}$ air 6- 7,Ph tanah 6- 7, kelembaban udara 62- 67\%, kekruhan75- $82 \mathrm{~cm}$. Didukung juga dengan data hasil penelitian menurut Putri et al (2011) kura- kura air tawar hidup baik pada suhu $25^{\circ} \mathrm{C}-32^{0} \mathrm{C}$, sedangkan pada suhu $27^{0}$ C- $30^{\circ} \mathrm{C}$ sistem daya tahan tubuh dapat bekerja dengan maksimal. Berdasarkan hasil pengukuran faktor abiotik dan pegukanuran laju pertumbuhan yang didapat diketahhui bahwa C.amboinensis dapat hidup dan bertumbuh cukup baik di kolam kehutanan sehingga dapat dijadikan area konservasi Cauro amboinensis dengan beberapa syarat. Syarat ini diberikan karena adanya pondasi beton yang menghalang C.amboinensis untuk keluar dan ke daratan untuk bertelur dan kembali lagi kekolam untuk mencari makan. Setelah itu dilakukan penelitian November 2016 untuk menangkap kura- kura yang telah dilepas di kolam tersebut dengan memasang 6 buah.

Berdasarkan Tabel 5, angket dengan instrumen pertama $22,8 \%$ pengetahuan mahasiswa tentang keberadaan 10 jenis kurakura di Sumatera masih sangat rendah. Meningkat setelah di berikan tretmen menjadi $77,2 \%$. Dilihat selisih atau rentang nilainya 
mengalami peningkatan yang cukup signifikan hampir setengahnya. Pada aspek penilaian konsep konservasi data awalnya 13\% meningkat menjadi 87\%. Dilihat deltanya perubahannya sangat besar $74 \%$. Berarti ada perubahan dan peningkatan pengetahuan tentang konsep konsep konservasi setelah kegiatan pelatihan. Pada aspek penilaian sikap konsevasi data awalnya rendah $34 \%$ setelah diberi treetmen meningkat 56\% namun dilihat delta perubahannya sangat rendah sekali.

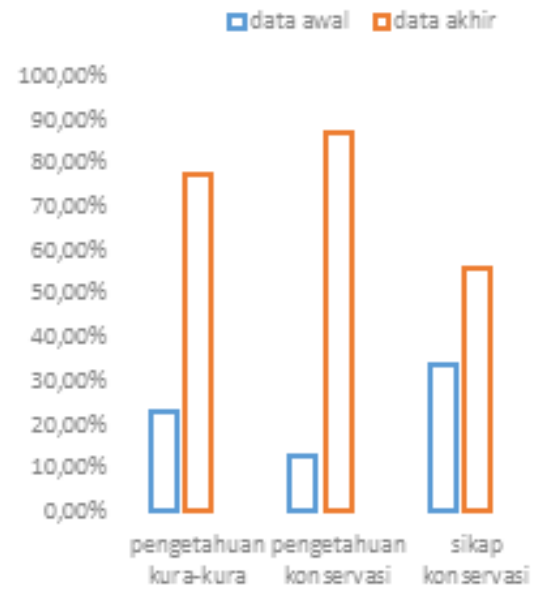

Gambar 1. Grafik perbandingan nilai aspek penilaian pada angket

Berdasarkan Gambar 1, pengetahuan mahasiswa tentang keberadaan 10 jenis kurakura di Sumatera sangat rendah. Namun pemahaman mahasiswa tentang konsep konservasi sangat tinggi, hanya sekitar $13 \%$ yang belum paham tentang konsep konservasi. Sedangkan pada sikap konservasi sangat rendah persentasenya. Setelah diberikan pengetahuan dan pemahaman tentang konsep konservasi dan keberadaan kura- kura disumatera tidak ada perubahan sikap konservasi. ini berarti perubahan sikapnya belum semua mahasiswa atau sangat rendah dibandingkan dua aspek penilaian yang lain. Seharusnya dengan pengenalan mereka terhadap keberadaan kura- kura dan tingginya pemahaman mereka tentang konsep konservasi sejalan dengan berubahnya sikap konservasi terhadap kura- kura tersebut. Tidak adanya perubahan terhadap sikap konservasi ini dikarenakan kegiatan ini dilakukan hanya 1 kali, itu tidak dapat merubah individu seseorang untuk berubah sikap konservasinya untuk itu harus dilakukan berulang- ulang. Selain itu seseorang harus memiliki rasa suka atau tidak suka terhadap konservasi lingkungan. Mempercayai sesuatu keadaan yang diberikan juga menjadi salah satu fakor mengapa sulit merubah sikap konservasi seseorang. Sedangkan kepercayaan merujuk kepada tahap penerimaan sesuatu yang benar atau salah. Selain itu harus ada strategi, platihan, teknik yang bisa bagus untuk diterima oleh mahasiswa agar terjadi perubahan sikap terhadap konservasi ex- situ yang dilakukan.

\section{KESIMPULAN}

Terjadi laju pertumbuhan (berat, panjang, lebar, lengkung AP, lengkung marginal, ketebalan karapaks) 10 ekor Cauro amboinensis yang diamati selama 3 pekan di kolam konservasi. Faktor abiotic mendukung pertumbuhan $C$. amboinensis sehingga cukup baik untuk dijadikan area konservasi kurakura batok (C. amboinensis). Selain itu juga terdapat peningkatan pengetahuan tentang konservasi terhadap mahasiswa dengan menggunakan bahan ajar yang telah diberikan namun tidak berpengaruh tehadap perubahan sikap konservasi, karena untum merubah sikap seseorang tidak bisa hanya 1 kali kegiatan harus berulang- ulang dan harus menggunakan strategi.

\section{DAFTAR PUSTAKA}

Astuti AP, Wiryono, Ruyani A. 2017. Pedoman Monitoring Kura-kura Semi Akuatik, Studi pada Kura-kura Garis Hitam (Cyclemys oldhamii). Bengkulu (ID): Unit Penerbit FKIP Universitas Bengkulu.

Astuti, A. P., Ruyani, A., \& Wiryono, W. 2017. Respons Mahasiswa Terhadap Buku Panduan Dan Kegiatan Pelatihan "Teknik Monitoring Kura-Kura Cyclemys oldhamii”. PENDIPA Journal of Science Education, 1(1).

Cempaka, I. 2015. Studi Cauro amboinensis di Lokasi Konservasi Ex- situ Taman Pintar FKIP Universitas Bengkulu dan Implementasinya Pada Pembelajaran Outdoor Bagi Siswa SMP (Sekolah Menengah Pertama) [Tesis]. Bengkulu: Universitas Bengkulu. 
Depdiknas. 2008. Perangkat Pembelajaran KTSP (Kurikulum Tingkat Satuan Pendidikan) SMA (Sekolah Menengah Atas). Jakarta: Depdiknas.

Iskandar, D. T. 2000. Kura- Kura dan Buaya Indonesia dan Papua Nugini dengan catatan mengenal jenis- jenis di Asia Tenggara. Bandung: ITB.

Ismi, M. G. 2016. Perubahan Profil Protein Otak Mus musculus Terinduksi HgCL2 dengan Pemberian Ekstrak Etlingera Hemisphaerica Dan Pengembangan Bahan Ajar Elektroforesis 2- D [Tesis]. Bengkulu: Universitas Bengkulu.
IUCN. 2013. Sixteenth Meeting of the Conference of the Parties, Consideration of Proposals for Amendments to Appendices I and II. Thailand (TH): Convention on International Trade in Endangered Species of Wild

Melinda, E. 2007 Pengaruh Resiko Kubis Putih (Brassica olerasea) dan Rucah Ayam Sebagai Pakan Serta Pengaruhnya Terhadap Pertumbuhan Kura-Kura Garis Hitam [Skripsi]. Bengkulu: Universitas Bengkulu. 